\title{
Evaluation of serum vitamin D levels in patients with lichen planus
}

\section{Liken planus hastalarında serum vitamin D seviyelerinin değerlendirilmesi}

\section{Deniz Aksu Arıca, ๑ Leyla Baykal Selçuk, ๑ Asım Örem*, ๑ Zeynep Karaca Ural, - Savaș Yaylı, ๑ Sevgi Bahadır}

Karadeniz Technical University Faculty of Medicine, Department of Dermatology and Venereology; *Department of Biochemistry, Trabzon, Turkey

\begin{abstract}
Background and Design: Lichen planus (LP) is a chronic inflammatory disease of unknown etiology that most commonly affects the skin and oral mucosa. Vitamin D is a steroid hormone with immunomodulatory, anti-inflammatory and antioxidant effects. The purpose of this study was to evaluate serum vitamin D levels in patients with LP and to compare these with those of healthy control subjects.

Materials and Methods: Forty-eight patients with a diagnosis of LP and 46 healthy controls were enrolled in the study. The serum levels of 25-hydroxy vitamin D, calcium, phosphate and parathyroid hormone were studied from blood samples collected from all subjects.

Results: The serum levels of vitamin D were lower in the LP patients compared to the controls and in the oral erosive LP patients compared to the other LP patients, although the difference was not statistically significant. There were no statistically significant differences in other laboratory parameters between the patient and the control groups.

Conclusion: Our study revealed no clear relation between LP and vitamin D levels. The results of our study suggest that other factors except vitamin D, particularly probable triggers, play a more dominant role in the immunopathogenesis of LP. Further studies with larger patient populations assessing serum vitamin D levels in different types of LP and vitamin D-related gene polymorphisms are now needed in order to reveal the relation between LP and Vitamin D more clearly.
\end{abstract}

Keywords: Lichen planus, vitamin D, etiology, oral lichen planus

Öz

Amaç: Liken planus (LP), etiyolojisi bilinmeyen, sıklıkla deri ve oral mukozayı etkileyen, kronik enflamatuvar bir hastalıktır. D vitamini immünomodülatör, anti-enflamatuvar ve antioksidan etkileri olan bir steroid hormondur. Bu çalışmanın amacı LP tanılı hastalarda serum D vitamin düzeylerini değerlendirmek ve bunları sağlıklı kontrol grubuyla karşılaştırmaktır.

Gereç ve Yöntem: Çalışmaya LP tanısı almış 46 hasta ve 46 sağ|ıkı kontrol alındı. Tüm olgulardan toplanan kan örneklerinden serum 25-hidroksi D vitamini, kalsiyum, fosfat ve paratiroid hormon düzeyleri çalışıldı.

Bulgular: Serum D vitamini düzeyleri LP'li hastalarda kontrollere göre ve oral erozif LP'li hastalarda diğer LP'li hastalara göre daha düşük bulundu, ancak fark istatistiksel olarak anlamlı değildi. Diğer laboratuvar parametrelerinde hasta ile kontrol grubu arasında istatistiksel olarak anlamlı fark yoktu.

Sonuç: Çalışmamız LP ve D vitamini düzeyleri arasında net bir ilişki olmadığını ortaya koydu. Çalışmamızın bulguları, D vitamini dışındaki diğer faktörlerin, özellikle olası tetikleyicilerin, LP'nin immünopatogenezinde daha baskın bir rol oynayabileceğini düşündürmektedir. LP ve D vitamini arasındaki ilişkiyi daha açık bir şekilde ortaya koymak için, farklı LP türlerinde serum D vitamini düzeylerini ve $D$ vitamini ile ilişkili gen polimorfizmlerini değerlendiren daha geniş hasta popülasyonları ile ileri çalışmalara ihtiyaç vardır.

Anahtar Kelimeler: Liken planus, vitamin D, etiyoloji, oral liken planus

Address for Correspondence/Yazışma Adresi: Deniz Aksu Arıca MD, Karadeniz Technical University Faculty of Medicine, Department of Dermatology and Venereology, Trabzon, Turkey Phone: +90 5436737173 E-mail: drdenizaksu@gmail.com

Received/Geliş Tarihi: 04.10.2019 Accepted/Kabul Tarihi: 21.05.2020 ORCID: orcid.org/0000-0003-3755-4325

CCopyright 2020 by Turkish Society of Dermatology and Venereology

Turkderm - Turkish Archives of Dermatology and Venereology published by Galenos Yayınevi. 


\section{Introduction}

Lichen planus (LP) is a chronic inflammatory disorder capable of involving the skin, mucous membranes and nails, with an estimated prevalence of approximately $1 \%$ of the global population'. Onset may occur at any age, but the condition usually develops in middle-aged adults.

The etiology of LP is still unclear. An immune-mediated mechanism involving activated CD8+ T cells, directed against basal keratinocytes and changes in epithelial keratinization have been proposed ${ }^{2}$. Previous researches have identified upregulation of intercellular adhesion molecule-1 and cytokines associated with a helper $\mathrm{T}$ cell type 1 (Th1) - driven immune response ${ }^{2-4}$. LP patients have high Th1/ Th2 ratios, suggesting that Th1 may play a dominant role in the immunopathogenesis ${ }^{5}$. The cytotoxic CD8+ $T$ lymphocytes that are stimulated following $\mathrm{MHC}$ class II antigen presentation by Langerhans cells to CD4+ T-helper cells, are thought to exhibit direct toxicity against keratinocyte antigens in the basal layer and cause degeneration in the basal layer 6 .

Vitamin $\mathrm{D}$ is a pleiotropic hormone principally responsible for regulating calcium and phosphorus homeostasis ${ }^{7}$. It has also been shown to possess anti-proliferative, pro-apoptotic, pro-differentiating, and antiangiogenic properties. A specialized nuclear hormone receptor, vitamin D receptor (VDR), is largely responsible for its biological function ${ }^{8}$. In physiological terms, vitamin $D$ regulates the differentiation and proliferation of keratinocytes, cutaneous immune system homeostasis, and the apoptotic process in the skin ${ }^{9,10}$.

Vitamin D also has a significant role in the regulation of immune responses and exhibits anti-inflammatory properties, ${ }^{7,11,12}$. Vitamin $D$ has been shown to exhibit effects including inhibition of T-helper 1 cell proliferation, stimulation of regulatory $T$ cells, suppression of $B$ lymphocyte differentiation, and the inhibition of immunoglobulin release. It also restricts antigen presentation and modulates dendritic cells maturation ${ }^{13}$. Vitamin D also down-regulates the expression and production of a number of pro-inflammatory cytokines, such as including tumor necrosis factor-alpha, and interleukin (IL)-1 $\beta$, IL-6, and $\mathrm{IL}-8^{14}$. Due to these immunomodulatory effects, vitamin $\mathrm{D}$ deficiency may lead to a decrease in regulatory $T$ cell numbers, and to a relative dominance of other $\mathrm{T}$ lymphocytes, such as Th1, involved in several inflammatory conditions, including LP. Vitamin D deficiency can therefore result in a disposition to the development of Th1-dominated diseases, such as $L P^{15,16}$.

The purpose of this study was to determine serum vitamin D levels in patients with LP, and to compare these with a control group. Only three studies to date have investigated serum vitamin D levels in patients with oral lichen planus (OLP), and their findings are inconsistent $t^{5,16,17}$.

\section{Materials and Methods}

\section{Study design and groups}

We initially intended to include all patients with a diagnosis of LP admitted to the clinics of the Department of Dermatology at the Faculty of Medicine, over a one-year period. The diagnosis of LP was made clinically in cases with typically clinical findings and/ or clinicopathologically in suspected cases. Fifty-six patients were diagnosed with LP during this period; however, seven of them were receiving systemic corticosteroid therapy and were excluded. Forty- eight patients with LP were thus finally enrolled as the patient group. The control group consisted of 46 healthy age- and sex-matched volunteers from the hospital staff with no dermatological disease. The same geographically-sourced population was employed for the case and control groups. The Fitzpatrick skin type of all cases ranged from two to three.

Approval for the study protocol was granted by the Karadeniz Teknik University Institutional Ethical Committee (approval number: 2016/75). All members of both groups provided informed consent prior to taking part in this study.

The inclusion criteria were: being at least 18 years old, and a willingness to participate. The exclusion criteria were: use of medications affecting serum vitamin D levels, such as vitamin D supplements of any kind, use of calcium and calcium channel blockers during the previous six months, presence of isolated oral mucosal lesions adjacent to amalgam restorations, or a history of chronic disease such as renal or hepatic diseases, bone metabolic disease, malabsorption, diabetes mellitus (DM), malignancies, thyroid or parathyroid disease. Pregnant women were also excluded.

All subjects' demographic characteristics, age, body mass index (BMI), medical profile and medications used were elicited by means of a questionnaire. Disease duration and clinical manifestations in the LP group were also recorded.

\section{Blood sample collection and analysis}

Serum 25-hydroxyvitamin D [25(OH)D] concentrations are the best indicators of vitamin D status. These were therefore examined in this study, as well as other biochemical parameters capable of affecting vitamin D levels, such as calcium, phosphate and parathyroid hormone (PTH), from blood samples collected from all subjects. Specimens were collected simultaneously by synchronously testing the pairs of patient and sex-age-matched controls between the months of October and June in order to avoid the patient and control laboratory analyses being affected by seasonal variation. Serum vitamin D levels lower than 20 $\mathrm{ng} / \mathrm{mL}$ were regarded as deficient, $20-30 \mathrm{ng} / \mathrm{mL}$ as insufficient, and 30-100 $\mathrm{ng} / \mathrm{mL}$ as sufficient ${ }^{7}$.

Venous blood samples were collected at 8.00-10.00 a.m. following overnight fasting. They were then placed into BD Vacutainer Serum Separating Tubes II Advance tubes and left to clot for $30 \mathrm{~min}$, followed by centrifugation at 3000 rpm for $10 \mathrm{~min}$. Serum [25(OH)D] and PTH levels were measured using the chemiluminescence immunoassay technique principle in Beckman Coulter DXI 800 (Beckman Coulter, USA). Serum calcium and phosphate levels were determined using colorimetric methods on a Beckman Coulter AU 5800 device (Beckman Coulter, Japan).

\section{Statistical Analysis}

Statistical analysis was performed on the Statistical Package for Social Sciences software (ver. 23.0; SPSS, Inc., Chicago, IL, USA). Descriptive data were expressed as number ( $n$ ) and percentage (\%), while other data were expressed as mean \pm standard deviation. Categorical variables were compared using chi-square analysis. Normal distribution was evaluated with the Kolmogorov-Smirnov test. Student's t-test was used to compare normally distributed constant variables, and the Mann-Whitney $U$ test for non-normally distributed variables. Spearman's correlation test was applied for correlation analysis. $\mathrm{P}<0.05$ were considered statistically significant. 


\section{Results}

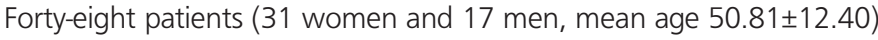

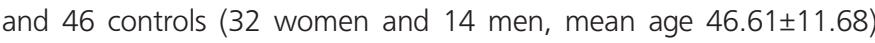
were included in the study. Cutaneous disease was present in 17 patients, mucocutaneous disease in 14, and mucosal lesions only in 17. Reticular lesions were present in 20 of the 31 patients with oral mucosa involvement and erosions in 11. The mean duration of symptoms in the patient group was $4.00 \pm 5.68$ years and it was significantly longer in the patients with erosive LP than in the other patients ( $p=0.001)$. The clinical data of the study population are shown in Table 1.

Mean BMI was significantly higher in the patients than in the controls $(p=0.011)$. No statistically significant differences were observed in other characteristics and laboratory parameters between the patient and control groups. Also we didn't find any significant correlation between BMI, disease duration and serum vitamin D levels. Serum vitamin D levels were lower in LP patients compared to the controls; and in erosive LP patients compared to those with non-erosive LP, although the differences were not statistically significant. The clinical characteristics and laboratory findings of patients with and without erosive LP are shown in Table 2.

When serum vitamin $D$ levels lower than $20 \mathrm{ng} / \mathrm{mL}$ were regarded as deficient, $20-30 \mathrm{ng} / \mathrm{mL}$ as insufficient, and $30-100 \mathrm{ng} / \mathrm{mL}$ as sufficient, insufficiency or deficiency was determined in a large part of both the patient and control groups. Serum vitamin D levels were sufficient in only five cases in total. Serum vitamin $D$ values were at toxic levels $(100 \mathrm{ng} / \mathrm{mL})$ neither in patients, nor in controls. Vitamin D levels were divided into three categories; deficient, insufficient and sufficient, in the patient and control groups are summarized in Table 3.

\section{Discussion}

Vitamin D deficiency is an important health problem across the world (affecting approximately 15\% of the population), even in regions where ultraviolet $B$ (UVB) radiation is thought to be sufficient ${ }^{18,19}$. The prevalence is higher in Middle Eastern countries, as in our Turkish study population. Although Turkey receives adequate sunlight, this high prevalence may have a number of causes, including decreased vitamin

Table 1. Characteristics and laboratory parameters between the patient and control groups

\begin{tabular}{|c|c|c|c|}
\hline & $\begin{array}{l}\text { Patients } \\
(n=48)\end{array}$ & $\begin{array}{l}\text { Control } \\
(n=46)\end{array}$ & $\mathrm{p}$ \\
\hline Age (years) & $50.81 \pm 12.40$ & $46.61 \pm 11.68$ & 0.052 \\
\hline \multicolumn{4}{|l|}{ Gender, n (\%) } \\
\hline Male & $17(35.4)$ & 14 & \multirow[t]{2}{*}{0.664} \\
\hline Female & $31(64.6)$ & 32 & \\
\hline Body mass index $\left(\mathrm{kg} / \mathrm{m}^{2}\right)$ & $29.14 \pm 5.81$ & $26.11 \pm 4.24$ & 0.011 * \\
\hline Vitamin D $(\mu \mathrm{g} / \mathrm{L})$ & $17.11 \pm 7.20$ & $18.39 \pm 9.37$ & 0.910 \\
\hline Calcium (mg/dL) & $9.78 \pm 0.34$ & $9.73 \pm 0.45$ & 0.587 \\
\hline PTH (pg/mL) & $45.68 \pm 17.77$ & $48.36 \pm 17.17$ & 0.514 \\
\hline Phosphate (mg/dL) & $3.64 \pm 0.45$ & $3.63 \pm 0.61$ & 0.945 \\
\hline
\end{tabular}

D photosynthesis in response to UVB in individuals with high skin melanin content, extensive covering of the skin (especially among girls and women), high sunscreen use, insufficient exposure to sunlight due to prolonged indoor activities and limited outside activities, insufficient intake of vitamin D through diet, and elevated obesity levels ${ }^{18,19}$

The most suitable metabolite for measuring serum vitamin D levels, which was also employed in the present study, is [25(OH)D $]^{19,20}$. This has a longer half-life than other metabolites (21-30 days), and thus provides a better reflection of vitamin $\mathrm{D}$ stores. The most active metabolite of vitamin $D$ is 1,25-dihydroxycholecalciferol $[1,25(\mathrm{OH}) 2 \mathrm{D} 3]$, but this has a short half-life (4-15 h), and while $25 \mathrm{OH}-\mathrm{D}$ is present at nanomoles per liter concentrations in circulation, $[1,25(\mathrm{OH}) 2 \mathrm{D} 3]$ is present at picomoles per liter concentrations.

There is no consensus on which level of serum vitamin D should be regarded as sufficient. The Institute of Medicine describes $50 \mathrm{nmol} / \mathrm{L}$ or above as a sufficient vitamin $D$ level, with lower levels being regarded as vitamin $D$ deficient ${ }^{21}$. In contrast, The Endocrine Society reports a minimum threshold value of $75 \mathrm{nmol} / \mathrm{L}^{22}$. In addition to this uncertainty over sufficiency thresholds, appropriate levels can even vary between individuals or in different cellular functions in the same individual (such as calcium phosphorus homeostasis or immunoregulatory effects) ${ }^{19}$. Numerous studies have observed lower vitamin D levels in various, autoimmune diseases including Behçet's disease, inflammatory bowel disease, rheumatoid arthritis, systemic lupus erythematosus, type 1 DM, and autoimmune diseases of the thyroid ${ }^{11,23-26}$. Serum vitamin $\mathrm{D}$ levels have also been shown to be inversely correlated with

Table 2. Laboratory parameters between the patients with and without erosive LP

\begin{tabular}{|c|c|c|c|}
\hline & $\begin{array}{l}\text { Patients } \\
\text { with erosive } \\
\text { LP }(n=11)\end{array}$ & $\begin{array}{l}\text { Patients } \\
\text { without } \\
\text { erosive LP } \\
(n=37)\end{array}$ & p \\
\hline Age (years) & $51.82 \pm 8.03$ & $49.70 \pm 12.99$ & 0.613 \\
\hline \multicolumn{4}{|l|}{ Gender, n (\%) } \\
\hline Male & 5 & 12 & \multirow[t]{2}{*}{0.486} \\
\hline Female & 6 & 25 & \\
\hline Duration of disease & $7.90 \pm 3.98$ & $4.14 \pm 5.87$ & $0.001^{*}$ \\
\hline Body mass index $\left(\mathrm{kg} / \mathrm{m}^{2}\right)$ & $30.54 \pm 4.95$ & $28.13 \pm 5.06$ & 0.151 \\
\hline Vitamin D $(\mu \mathrm{g} / \mathrm{L})$ & $16.29 \pm 5.08$ & $17.40 \pm 8.09$ & 0.582 \\
\hline Calcium (mg/dL) & $9.56 \pm 0.21$ & $9.87 \pm 0.36$ & 0.130 \\
\hline PTH $(\mathrm{pg} / \mathrm{mL})$ & $57.72 \pm 19.04$ & $45.34 \pm 17.24$ & 0.081 \\
\hline Phosphate (mg/dL) & $3.54 \pm 0.33$ & $3.62 \pm 0.48$ & 0.611 \\
\hline
\end{tabular}

Table 3. Distribution of patient and control group cases based on serum vitamin $D$ levels

\begin{tabular}{|l|l|l|l|}
\hline \multicolumn{2}{|c|}{} & $\begin{array}{l}\text { Patient } \\
\mathbf{n = 4 8}(\%)\end{array}$ & $\begin{array}{l}\text { Control } \\
\mathbf{n = 4 6}(\%)\end{array}$ \\
\hline \multirow{2}{*}{$\begin{array}{l}\text { Vitamin D } \\
(\mathrm{ng} / \mathrm{mL})\end{array}$} & $<20$ (deficient) & $31(47.0)$ & $35(53.0)$ \\
\cline { 2 - 4 } & $20-30$ (insufficient) & $13(59.1)$ & $9(40.9)$ \\
\cline { 2 - 4 } & $30-100$ (sufficient) & $2(40.0)$ & $3(60.0)$ \\
\hline
\end{tabular}


disease activity in some of these conditions ${ }^{24,25}$. Determination of low levels in autoimmune diseases has led to research focusing on the immunoregulatory role of vitamin D.

Our aim in this study was to determine serum vitamin $D$ levels in patients with LP, a chronic inflammatory disease, and to assess their relation with disease severity by comparing them with those of a control group. To the best of our knowledge, there have been only one case report and three case-controlled studies of serum vitamin D levels in LP patients $5,16,17,27$. These studies were performed in societies in which vitamin D deficiency is widespread, and the results are inconsistent. The relation between LP and serum vitamin D levels was first emphasized in a case report from India by Varma et al. ${ }^{27}$ in 2014 . Those authors reported low vitamin D levels in three cases of OLP, one with accompanying cutaneous LP ${ }^{27}$. Partial improvement in mucosal lesions and complete resolution of paresthesia with oral vitamin D support were reported, although it is difficult to attribute the improvement to vitamin $\mathrm{D}$ alone since the patient was also being treated for $\mathrm{LP}^{27}$.

The first case-controlled study to compare serum vitamin D levels in LP patients was performed in Northern India by Gupta et al. ${ }^{17}$ and published in 2017. In that study, the serum vitamin D levels of 102 patients with OLP were compared with those of 102 controls using the Enzyme Linked Fluorescent Assay method, and mean serum vitamin D levels were significantly lower in the OLP group compared to the controls $(20.40 \mathrm{ng} / \mathrm{mL}$ in the patient group and $32.67 \mathrm{ng} / \mathrm{mL}$ in the control group). In Gupta et al.' $\mathrm{s}^{17}$ study, vitamin D deficiency was significantly more prevalent in the OLP patients, and vitamin D insufficiency being more common in the control group suggests that vitamin D deficiency is a significant problem in the study population. At the same time, serum vitamin D levels exceeded $100 \mathrm{ng} / \mathrm{mL}$ in eight cases in the study of Gupta et al. ${ }^{17}$ (four controls and four patients), suggesting that the selected study population may have been exposed to vitamin D in some manner. The study also emphasized that the severity of oral lesions increased with the degree of vitamin D deficiency. Erosive and atrophic lesions and severe paresthesia and pain were determined in a higher proportion of patients with vitamin D deficiency compared to those with insufficiency $(52.77 \%$ vs $47.05 \%)$, although the difference was not statistically significant. Serum vitamin D levels were also found to be lower in patients with oral erosive LP compared to the other LP patients in our study, but the difference was not statistically significant either. Vitamin $D$ deficiency may be associated with the severity of the disease, but further studies are required in order to confirm this theory. In a study from China published in 2017, Du et al. ${ }^{5}$ analyzed serum and oral mucosa biopsy specimens from 14 OLP patients. Serum [25(OH)D] levels measured using enzyme immunoassays were lower in the OLP patients than in the controls, and VDR expression was shown to be down-regulated in OLP tissues. These findings were linked to activated Th1 - driven inflammatory response in the pathogenesis of LP5. However, the low number of cases in that study makes it impossible to effectively generalize the results. Another study by the same team showed that vitamin D/VDR signalled suppressed oral keratinocyte apoptosis in LP. ${ }^{28}$ A third study, conducted in Iran by Bahramian et al. ${ }^{16}$, was published in 2018. The serum [25(OH)D] levels of 18 patients with OLP were compared with those of 18 healthy controls using electrochemiluminescence. The season during which the specimens were collected in that study was not reported. Similarly, in our study serum vitamin $D$ levels were lower in the OLP patients than in the control group, but the difference was not statistically significant.

Although serum vitamin $D$ is today thought to be less affected by exposure to sunlight and the seasons, ${ }^{18}$ since there is known to be some degree of seasonal variation between summer and winter in serum vitamin D levels, ${ }^{29}$ our patient and control groups were selected simultaneously, and during enrolment of the study population we avoided periods of intense sunlight exposure.

Serum vitamin D levels may be expected to be higher in summer, when exposure to UVB is most intense. Gupta et al. ${ }^{17}$ determined a higher proportion of vitamin D deficiency in the pre-monsoon season, when the fewest patients were identified, compared to the summer monsoon season, when the most patients were identified (83.3\%73.5\%). In another study from India, the highest incidence of OLP was reported in summer and the lowest incidence in winter ${ }^{30}$. This inconsistency between vitamin D levels in serum and the seasonal incidence of OLP suggests that LP development may not be directly associated with vitamin D levels.

In our study, the only parameter which shows statistically significant difference between patient and control groups is BMI. The higher BMI may be an expected finding in patients with LP due to chronic inflammation, as emphasized in previous studies ${ }^{31}$. Evidence also suggests a direct association between higher BMI and vitamin D insufficiency ${ }^{32}$, however we couldn't find any significant corelation between BMI and serum vitamin D levels in our study.

\section{Study Limitations}

The inconsistency between our findings and some of the studies cited above may be ascribed to heterogeneity in the type of disease (cutaneous and/or mucosal involvement) and its activity (such as active disease and clinical remission), and to a number of factors impacting on serum vitamin D serum levels, such as the season when sampling took place, the length of exposure to sunlight, ethnic and/or geographical variations, parameters including BMI and age, the various methods employed for vitamin D level calculation, and nutrition status as a confounding factor ${ }^{16,33}$. The effects of vitamin $D$ may be affected by the presence of single nucleotide polymorphisms in vitamin D-related genes, such as VDR and cytochrome $P 450$ genes with known roles in vitamin D metabolism ${ }^{33,34}$. Sufficient vitamin D levels for each function may vary depending on the status of these gene polymorphisms in society.

\section{Conclusion}

Serum vitamin D levels in our study were lower in the LP patients than in the controls, and in patients with erosive OLP, the severe disease form, compared to the other patients, although the differences were not statistically significant. Vitamin D deficiency is an important and ubiquitous health problem. In assessing the relation between diseases and vitamin D levels, it is not sufficient to investigate serum vitamin $D$ levels alone. More accurate information concerning the place of vitamin $D$ in the pathogenesis of LP and its relation with severity of disease may be obtained through studies investigating serum vitamin $D$ levels together with vitamin D-related gene polymorphism in different disease types in LP and larger patient populations. 
Vitamin D support may well be beneficial in the resolution of problems in immune system activity in immune-mediated diseases. However, since existing studies, including the present research, have not fully revealed the relation between LP and vitamin D levels, this suggests that the role of vitamin D in the immunopathogenesis of LP is not as clear as had been anticipated, and that other factors, particularly probable triggers, may play a more dominant role.

\section{Ethics}

Ethics Committee Approval: This study was approved by the Ethics Committee of Karadeniz Technical University (approval number: 2016/75).

Informed Consent: Informed consent was taken from all patients and controls.

Peer-review: Externally peer-reviewed.

\section{Authorship Contributions}

Surgical and Medical Practices: D.A.A., Concept: D.A.A., Design: D.A.A., Data Collection or Processing: D.A.A., L.B.S., A.Ö., Z.K.U., S.Y., S.B., Analysis or Interpretation: D.A.A., L.B.S., A.Ö., Z.K.U., Literature Search: D.A.A., Writing: D.A.A.

Conflict of Interest: The authors have no conflicts of interest to declare.

Financial Disclosure: This study was supported by the Scientific Research Unit of Karadeniz Technical University, under Project number 5622.

\section{References}

1. Le Cleach L, Chosidow O: Clinical practice. Lichen planus. N Engl J Med 2012;366:723-32.

2. Lehman JS, Tollefson MM, Gibson LE: Lichen planus. Int I Dermatol 2009;48:682-94.

3. Chen X, Liu Z, Yue Q: The expression of TNF-alpha and ICAM-1 in lesions of lichen planus and its implication. J Huazhong Univ Sci Technolog Med Sci 2007;27:739-41.

4. Rhodus NL, Cheng B, Ondrey F: Th1/Th2 cytokine ratio in tissue transudates from patients with oral lichen planus. Mediators Inflamm 2007;2007:19854.

5. Du J, Li R, Yu F, et al: Experimental study on 1,25(OH)(2) D(3) amelioration of oral lichen planus through regulating NF- B signaling pathway. Oral Dis 2017:23:770-8

6. Ryan K, Hegarty AM, Hodgson T: Aetiology, diagnosis and treatment of oral lichen planus. Br J Hosp Med (Lond) 2014;75:492-6.

7. Holick MF: Vitamin D deficiency. N Engl J Med 2007;357:266-81.

8. Haussler MR, Whitfield GK, Haussler CA, et al: The nuclear vitamin D receptor: biological and molecular regulatory properties revealed. J Bone Miner Res 1998;13:325-49.

9. Barrea L, Savanelli MC, Di Somma C, et al: Vitamin D and its role in psoriasis: An overview of the dermatologist and nutritionist. Rev Endocr Metab Disord 2017;18:195-205

10. Matsumoto $K$, Hashimoto $K$, Nishida $Y$, Hashiro $M$, Yoshikawa $K$ : Growth-inhibitory effects of 1,25-dihydroxyvitamin D3 on normal human keratinocytes cultured in serum-free medium. Biochem Biophys Res Commun 1990;166:916-23.

11. Van Belle TL, Gysemans C, Mathieu C: Vitamin D in autoimmune, infectious and allergic diseases: a vital player? Best Pract Res Clin Endocrinol Metab 2011;25:617-32.

12. Mehmood ZH, Papandreou D: An updated mini review of vitamin d and obesity: adipogenesis and Inflammation state. Open Access Maced J Med Sci 2016:4:526-32.
13. Neve A, Corrado A, Cantatore FP: Immunomodulatory effects of vitamin $D$ in peripheral blood monocyte-derived macrophages from patients with rheumatoid arthritis. Clin Exp Med 2014;14:275-83.

14. Calton EK, Keane KN, Newsholme P, Soares MJ: The impact of vitamin D levels on inflammatory status: a systematic review of immune cell studies. PLoS One 2015;10:e0141770.

15. Mahon BD, Wittke A, Weaver $V$, Cantorna MT: The targets of vitamin $D$ depend on the differentiation and activation status of CD4 positive T cells. J Cell Biochem 2003;89:922-32.

16. Bahramian A, Bahramian $M$, Mehdipour $M$, et al: comparing vitamin d serum levels in patients with oral lichen planus and healthy subjects. J Dent (Shiraz) 2018;19:212-6.

17. Gupta A, Sasankoti Mohan RP, Kamarthi N, Malik S, Goel S, Gupta S: Serum vitamin $\mathrm{D}$ level in oral lichen planus patients of north india- a case-control study. J Dermatol Res Ther 2017;1:3:1-17.

18. Palacios C, Gonzalez L: Is vitamin D deficiency a major global public health problem? J Steroid Biochem Mol Biol 2014;144:138-45.

19. Nair P, Venkatesh B, Center JR: Vitamin D deficiency and supplementation in critical illness-the known knowns and known unknowns. Crit Care 2018;22:276

20. Vitamin D and Health in the 21st Century: an Update. Proceedings of a conference held September 2007 in Bethesda, Maryland, USA. Am J Clin Nutr 2008;88:483S-592S.

21. Ross AC, Manson JE, Abrams SA, et al: The 2011 report on dietary reference intakes for calcium and vitamin D from the Institute of Medicine: what clinicians need to know. J Clin Endocrinol Metab 2011;96:53-8.

22. Holick MF, Binkley NC, Bischoff-Ferrari HA, et al: Endocrine Society. Evaluation, treatment, and prevention of vitamin D deficiency: an Endocrine Society clinical practice guideline. J Clin Endocrinol Metab 2011;96:1911-30.

23. Faezi ST, Ansari N, Paragomi P, Akhlaghi M, Ghanavat M, Davatchi F: Vitamin D deficiency in patients with Behcet's disease. J Diabetes Metab Disord 2014;13:18

24. Fakharan M, Haghighi A, Arabi M, Loghman M: Investigating the levels of serum vitamin $d$ in patients with rheumatoid arthritis referred to rasoulakram hospital during 2011-2012. Iran J Med Sci 2014;39:476-9.

25. Schoindre $Y$, Jallouli M, Tanguy ML, et al: Group PLUS. Lower vitamin D levels are associated with higher systemic lupus erythematosus activity, but not predictive of disease flare-up. Lupus Sci Med 2014;1:e000027.

26. Froicu M, Weaver V, Wynn TA, McDowell MA, Welsh JE, Cantorna MT: A crucial role for the vitamin $D$ receptor in experimental inflammatory bowel diseases. Mol Endocrinol 2003;17:2386-92.

27. Varma RB, Valappila NJ, Pai A, Saddu SC, Mathew N: Oral Lichen Planus: Is Vitamin D Deficiency a Predisposing Factor? A Case Report. Int I Sci Study 2014;2:230-2.

28. Zhao $B, X u N$, Li R, et al: Vitamin D/VDR signaling suppresses microRNA802 -induced apoptosis of keratinocytes in oral lichen planus. FASEB 2019;33:1042-50

29. Urashima M, Segawa T, Okazaki M, Kurihara M, Wada Y, Ida H: Randomized trial of vitamin D supplementation to prevent seasonal influenza $A$ in schoolchildren. Am J Clin Nutr 2010;91:1255-60.

30. Mohan RPS, Ghanta S, Verma S, Agarwal N, Gupta N, Singh U. Meteorological influences on the incidence of lichen planus in a north Indian population. J Oral Sci 2013;55:311-8.

31. Arias-Santiago S, Buendía-Eisman A, Aneiros-Fernández J, et al: Cardiovascular risk factors in patients with lichen planus. Am J Med 2011;124:543-8.

32. Samuel L, Borrell LN: The effect of body mass index on optimal vitamin D status in U.S. adults: the National Health and Nutrition Examination Survey 2001-2006. Ann Epidemiol 2013;23:409-14.

33. Kujundzic B, Zeljic K, Supic G, et al: Association of vdr, cyp27b1, cyp24a1 and mthfr gene polymorphisms with oral lichen planus risk. Clin Oral Investig 2016;20:781-9.

34. Uitterlinden AG, Fang Y, Van Meurs JB, Pols HA, Van Leeuwen JP: Genetics and biology of vitamin D receptor polymorphisms. Gene 2004;338:143-56. 